Article

\title{
Research-Based Training: Methodological Characteristics and Results of the Analysis of Educational Programs
}

\author{
Roman O. Pavliuk* (D), Tetiana L. Liakh, Olga V. Bezpalko and Nataliia A. Klishevych \\ Institute of Human Sciences, Borys Grinchenko Kyiv University, 18/2 Ihor Shamo Blvd, 02154 Kyiv, Ukraine; \\ t.liakh@kubg.edu.ua (T.L.L.); o.bezpalko@kubg.edu.ua (O.V.B.); n.klishevych@kubg.edu.ua (N.A.K.) \\ * Correspondence: r.pavliuk@kubg.edu.ua; Tel.: +38-050-699-8421
}

Received: 25 September 2017; Accepted: 14 December 2017; Published: 19 December 2017

\begin{abstract}
The purpose of the article is to determine the peculiarities of using teaching elements of research-based training at the Institute of Human Sciences at Borys Grinchenko Kyiv University. Based on focus group methodology, the authors identify the key methodological characteristics of research-based training, which have comprised the basis of educational program analysis for determining the application of tasks that contribute to the development of students' research skills. The study used a focus group method. Its purpose was to obtain the necessary information from the participants to describe the methodological basis and justification of methods, forms, indicators, etc. of research-based training systems among people who are competent and have experience in this field. After that, the method of "theoretical sampling" was used, which enabled formulation of generalized characteristics according to the results of focus groups. The practical value of the study is the determination of the methodological characteristics of research-based training, which is the basis for the application of tasks by university teachers that promote the development of research competence in students. The research is one of the first attempts to determine the methodological characteristics of research-based training in Ukraine.
\end{abstract}

Keywords: research-based training; methodological characteristics; development of research skills

\section{Introduction}

The modern educational environment in Ukraine is in the process of transition to a new system of quality assurance of education, with an understanding of the transformational processes taking place in the political, economic, educational, scientific and technical fields.

Reforms in the higher education system (according to the Law on Higher Education of 2014) and in the scientific and technical sector (according to the Law on Scientific and Scientific and Technical Activities of 2015) provide sample opportunities for the training of highly skilled specialists and clearly regulate the educational and scientific policies of modern universities and research institutions. The changes to these laws include training of specialists in terms of higher education and life-long education, primarily through research techniques, using research-based learning.

There are a lot of practical examples of using of a research-based training system, research on its methodological background and its positive experimental results, but in Ukraine it is considered to be a component of university students' research/scientific work. Some aspects of research-based training as a component of research work can be found in the study of: (i) higher education teachers' preparation models in terms of a magistracy (Batechko 2016; Fedirchyk 2016); (ii) the design of open education systems (Pryima 2016); (iii) students' research activity systems (bachelor/magistracy) (Bondarenko 2014); and (iv) development of student's scientific activity as a component of professional training (Lutsenko 2011; Proshkin 2012). Consequently, we can confidently say that a research-based 
training system in Ukraine has not been developed, implemented and tested effectively at either the theoretical level or in practice.

Modernization of the training system for specialists within different specialties abroad takes place in the context of improving of educational services to meet the needs of the new society. These trends are currently observed in Ukraine. They gain special importance in connection with the active introduction of the best European and world experience in the higher education system and common European integration processes.

In addition to internal state education reforms, the professional training of specialists is influenced by world trends in the renewal of the educational environment. For example, at the World Economic Forum (Davos, Switzerland, 2016), experts presented the key skills that a successful specialist should have in 2020: (i) integrated problem solving; (ii) critical thinking; (iii) creativity; (iv) human management; (v) coordination with others; (vi) emotional intelligence; (vii) judgment making and decision making; (viii) service orientation; (ix) interaction; (x) negotiation; and (xi) cognitive flexibility.

So now we can talk about the serious contradictions between increased interest in the implementation of a research-based training system in the practice of modern higher education and the lack of justification of the methodological principles of this process; social order on the level of scientific skills, skills on monitoring and evaluation of social processes and methods, forms of scientific and professional training in higher educational institutions; the absence of comprehensive studies in Ukraine on the problems of a research-based training system and the objective need for understanding and rational application of practical research in this area.

Leading European and world universities in the middle of the last century have made major reforms on the effective integration of research and education, including the development of universities as the main center of the latest research using best research-based training practices.

The system of research-based training has become widely developed in foreign higher educational institutions as a type of active learning (Wildt 2010; Ludwig 2011), which can be implemented through specific forms, and which has its own features and specifications. In addition, research-based training is a unifying concept that covers a range of pedagogical approaches in the process of students' professional training aimed at the development of research skills (formulation and problem solving) (Aditomo et al. 2013).

Our analysis of foreign research of research-based training made it possible to isolate its general approaches and concepts of development. Some foreign researchers (Lageman 2002; Dewey 1933) relate the emergence of research-based training with the distinction of pedagogical research from the psychological system. This was preceded by a general scientific study in the system of joint sciences (for example, the humanities). Such a statement originates from the first half of the 20th century. In many foreign studies research-based training is associated with project training-a student prepares a graduation work on the basis of a lengthy study on an interdisciplinary basis (Abbott and McKinney 2013; Baldwing 2005; Blackmore and Fraser 2007; Thomas 2000; etc.). In addition, it is known from the history of science and education that the views and activities of the German scientist Wilhelm von Humboldt (Humbold 1984) are a classic and first example of the introduction of a research-based learning system. His ideas about the unity of science and education date back to the beginning of the 19th century. American scientist John Dewey, more than a hundred years ago, expresses a similar view-study through action, verification. The current understanding of research-based training has been developed since the 1970s (Spoken-Smith and Walker 2010). Due to this, now we have a significant foreign arsenal of research in the methodology of research-based training. Thus, foreign studies have convincingly shown that research-based learning contributes to student-centered learning, aimed at the fulfillment of student needs (Justice et al. 2009; Prince and Felder 2006, 2007), and contributes to the implementation of the scientific potential of the teaching staff of a higher educational institution (Healy 2005). Research-based training can be realized as a means of understanding science, and as a method of teaching (Spoken-Smith and Walker 2010). 
In our research paper we understand research-based training as a form of learning/training that has its purpose, content, methods, forms of organization and tools, and can be implemented by using a specific set of learning technologies. Confirmation of such an opinion is found in the research of well-known foreign scientists, which was concerned with the methodological basis of research-based training. Therefore, the confirmation that research-based training cannot be a form of organization training are found in the research of Prince and Felder (Prince and Felder 2006); Mills and Treagust (Mills and Treagust 2003), who argue that research-based learning can be implemented through certain organizational forms: problem-oriented learning, project-oriented learning, learning based on case techniques/technologies. That is, these forms of organization of teaching contribute to the implementation of research-based training as a type of training. Ifenthaler and Gosper (Ifenthaler and Gosper 2014), on the basis of theoretical and empirical research, argue that "research-based training is based on a multidisciplinary approach for the application of diverse goals and strategies training for the purpose of interconnected and logical conducting of research and teaching/instruction". Levy and Petrulis (Levy and Petrulis 2012) in many of their writings have repeatedly argued that research-based training embraces a fairly wide range of pedagogical goals. This means that the concept of research-based training is very broad and according to our deep conviction (and according to research by leading foreign scholars in this field) this is a type of study.

Consequently, according to the results of studies of foreign scientists, we can conclude that research-based learning is a complex of pedagogical goals, which are united by the main tasks of developing research competence in students (development of skills for setting a research task and finding ways to solve it).

\section{Results}

As a result of the first stage of the study, the activities of two focus groups, the main methodological characteristics of research-based training were identified. The division into more- and less-experienced participants was not effective as we got very similar content responses from experienced and less-experienced participants in focus groups. We give below these methodological characteristics.

Research-based training is a complex of pedagogical goals which are united by the main tasks of developing research competence of students (development of skills for setting a research task and finding ways to solve it).

Research-based training as a type of study has the following features:

- A set of student-centered learning and teaching goals that are realized through research;

- Teaching students by setting up specific tasks that involve the interpretation of experimental data, case studies (tasks) for analysis or a set of real-life situations/problems for solving;

- A set of tasks that contain specific instructions and which promote student-oriented and consulting research (the teacher is a consultant);

- Management of the learning process is done by setting questions and problems/practical tasks;

- Training is based on the search for novelty and its relevance;

- Implication of student-centered learning where the teacher is a facilitator.

Learning objectives of research-based training are:

- Formation of knowledge about science as a holistic and integrated education;

- Development of skills for determining the novelty and relevance of the research (through conducting own research and verification of its evidence).

Teaching methods of research-based training are:

- Search/research activities aimed at solving self-identified issues/problems in an unexplored/underdeveloped field;

- Search for new knowledge, solving a research problem set by a teacher; 
- Situational analysis of research results through verification of their evidence using their methodology.

Key research-based training elements are the research questions and problem situations that require pilot testing.

The main subtypes of research-based training are:

- Problem-oriented learning (focused on the process of solving the problem/in the process of research, the main goal is the definition of new, unexplored);

- $\quad$ Project-oriented training (focused on product development; the main goal is to determine the practical use of research results);

- $\quad$ Evidence-based training (can be verified practically).

Forms of study of research-based training are:

- Content-oriented learning (studying the general methodology of science);

- Practically oriented training (participating in short-term or fundamental academic studies);

- Applied research (aimed at solving practical problems or providing practical recommendations);

- Academic comprehensive research;

- $\quad$ Simplified research (research by model, algorithm or methodology developed by others);

- Research on the basis of literature analysis (theoretical research, development);

- Discussion on a specific scientific topic (with the selection of unexplored aspects and when the result is a new knowledge).

Main types of tasks and forms of work of research-based training are: (i) case studies; (ii) project tasks; (iii) problem-search tasks; (iv) brain-storming; (v) focus group; (vi) polls (surveys, interviews etc.); (vii) press conference, discussion; and (viii) presentation (research results).

The role of students in research-based training is characterized as active participants in the research process (producing ideas, determining relevance, engaging in research, developing methodologies, empirical studies, etc.).

After working out the methodological characteristics, each employee of the department of the Institute of Human Sciences at Borys Grinchenko Kyiv University had to analyze his own educational program of disciplines. The examples of analysis results are presented in the Table 1.

Here is a sample of tasks that meet core characteristics of research-based training.

Table 1. Results of the analysis of educational disciplines for the presence of tasks that match the characteristics of research-based training.

\begin{tabular}{ll}
\hline Subjects & Examples of Tasks that Match the Characteristics of Research-Based Training \\
\hline & Independent work 7. Professional activity of a specialist of the social sphere \\
& What specific skills and abilities must the future manager have to be ready for \\
public administration in the social sphere? & The order of the task: \\
& Make a questionnaire whose purpose is to determine the readiness of the future \\
& social worker for public administration in the social sphere. All questions in the \\
& questionnaire must be grouped into the following four blocks: \\
& - The urgency of the issue (what is)? \\
6th year, masters, & - How to solve a question (what should be)? \\
administration & - What arguments can be used to resolve the issue (why)? \\
& - What do you need to do (action)? It is necessary to clearly formulate a "call" for \\
& actions that will lead to a proper resolution of the issue. \\
& Ask at least 10 respondents (5 students and 5 specialists). \\
& Analyze the completed questionnaire. \\
& Present the results in the form of an Argument Card. \\
& Try to evaluate your readiness for public administration in the social sphere by \\
& creating an appropriate scale of criteria and indicators.
\end{tabular}


Table 1. Cont.

\begin{tabular}{|c|c|c|}
\hline Subjects & Course, Specialty & Examples of Tasks that Match the Characteristics of Research-Based Training \\
\hline \multirow{21}{*}{$\begin{array}{l}\text { Basics of } \\
\text { career } \\
\text { guidance }\end{array}$} & \multirow{21}{*}{$\begin{array}{l}\text { 2nd year, Bachelor, } \\
\text { Practical Psychology }\end{array}$} & $\begin{array}{l}\text { Determination of the readiness of the graduate to choose a profession. } \\
\text { An indicator of the readiness of the graduate to choose a profession is the } \\
\text { availability of a professional plan. } \\
\text { A personal professional plan is an image of a professional way, a model of } \\
\text { professional self-determination of a person. It is important to construct it } \\
\text { realistically, logically, clearly. } \\
\text { Having a professional plan means: (i) determination of the profession you want } \\
\text { to choose; and (ii) determination of the educational institution where you can get } \\
\text { the chosen profession. } \\
\text { The substantiated professional plan is based on: (i) knowledge of the content and } \\
\text { requirements of the profession; (ii) awareness of the suitability of the chosen } \\
\text { profession; and (iii) a real assessment of the possibility of admission to a selected } \\
\text { educational institution. } \\
\text { A professional plan must include (sample): }\end{array}$ \\
\hline & & $\begin{array}{l}\text { 1. Determination of the main professional goal (who to become, what to } \\
\text { achieve, etc.), establishing its conformity with other life goals. }\end{array}$ \\
\hline & & $\begin{array}{l}\text { 2. Determining the closest and long-term specific goals (to finish school, to } \\
\text { apply the university). }\end{array}$ \\
\hline & & 3. Ways and means of achieving goals (how to reach; with whose help, etc.) \\
\hline & & $\begin{array}{l}\text { 4. Spare options for achieving the goal in case of insurmountable difficulties } \\
\text { (including recourse to the employment center). }\end{array}$ \\
\hline & & $\begin{array}{l}\text { 5xternal conditions for the achievement of similar goals (form of study, } \\
\text { place of study, etc.). }\end{array}$ \\
\hline & & $\begin{array}{l}\text { 6. Acquaintance with the information on the chosen profession (working } \\
\text { conditions, technology, requirements for the qualities of a specialist, etc.). }\end{array}$ \\
\hline & & $\begin{array}{l}\text { 7. Cognition of own capabilities in the chosen activity (selection of } \\
\text { techniques, identification of individual psychological features). }\end{array}$ \\
\hline & & Matching own capabilities with the requirements of the profession. \\
\hline & & Awareness of the possible efforts to acquire a profession. \\
\hline & & $\begin{array}{l}\text { 10. Identification of ways of self-development for mastering the future } \\
\text { profession (self-education, studying of additional literature, consulting to } \\
\text { specialists). }\end{array}$ \\
\hline & & $\begin{array}{l}\text { 11. Identification of objective difficulties, possible obstacles on the way to } \\
\text { achieving the goal. }\end{array}$ \\
\hline & & 12. Awareness of your responsibility for the decision to choose a profession. \\
\hline & & $\begin{array}{l}\text { Tasks for students. } \\
\text { The task is offered to group of } 3-4 \text { students; the results are presented and } \\
\text { discussed at a practical lesson. The deadline is } 3 \text { weeks. } \\
\text { Aim: To determine the readiness to choose the profession of a (real) senior } \\
\text { school pupil. } \\
\text { Task: }\end{array}$ \\
\hline & & See a sample of your personal career plan. \\
\hline & & $\begin{array}{l}\text { 2. Find and agree with a senior school pupil about his participation in } \\
\text { the study. }\end{array}$ \\
\hline & & $\begin{array}{l}\text { 3. Conduct an advisory interview with a senior school pupil and get } \\
\text { information on all points in the plan. }\end{array}$ \\
\hline & & $\begin{array}{l}\text { Make a selection of techniques for identifying the individual psychological } \\
\text { characteristics of the senior school pupil (6-point plan). }\end{array}$ \\
\hline & & $\begin{array}{l}\text { 5. Conduct research on the identification of the individual psychological } \\
\text { characteristics of the senior school pupil using selected techniques. }\end{array}$ \\
\hline & & $\begin{array}{l}\text { 6. Create a personal professional plan for a senior school pupil } 1 \text { (for all } \\
\text { sample points). }\end{array}$ \\
\hline & & $\begin{array}{l}\text { Make a presentation of this plan identifying the readiness of the senior school } \\
\text { pupil to choose a profession. }\end{array}$ \\
\hline
\end{tabular}

After the teachers' introspection of their educational programs of disciplines, the focus groups were reoccupied. This activity was organized for the purpose of studying the experience of the staff of the Institute of Human Sciences at Borys Grinchenko Kyiv University and expert analysis of their assigned tasks, which, in their opinion, correspond to the characteristics of research-based training. The purpose of the re-activity of the focus groups was for critical analysis of the assigned tasks for their full compliance with the pre-developed methodological characteristics of research-based training. 
The quantitative characteristics of self-examination by teachers of their own educational programs and the analysis of participants in the focus group are presented in Table 2.

Table 2. Generalized results of educational programs analysis.

\begin{tabular}{cccc}
\hline Educational Level & Total Disciplines/Modules & $\begin{array}{c}\text { With Research Tasks } \\
\text { (Introspection of Lecturers) }\end{array}$ & $\begin{array}{c}\text { Fully Meet the Signs (Analysis of } \\
\text { Participants in the Focus Group) }\end{array}$ \\
\hline Bachelor & $335(100 \%)$ & $60(18 \%)$ & $14(4 \%)$ \\
Master & $131(100 \%)$ & $41(31 \%)$ & $31(24 \%)$ \\
All educational levels & $466(100 \%)$ & $101(22 \%)$ & $45(10 \%)$ \\
\hline
\end{tabular}

Let us explain some of the quantitative indicators presented in Table 2. A Bachelor's degree at the Institute of Human Science includes five specialties: (i) Social Work; (ii) Social Pedagogy; (iii) Psychology; (iv) Practical Psychology; and (v) Special Education (speech therapy). The total amount of academic groups is 28 . The educational program consists of 335 disciplines across four years of study. A Master's degree includes the same five specialties, 10 academic groups and 131 disciplines across two years of study.

As a result of teachers' self-examination there were identified tasks in 60 subjects (18\%) at the Bachelor's degree level that correspond to the methodological characteristics of research-based training. However, participants of the focus group as a result of the critical analysis of teachers' self-examination noticed only 14 disciplines whose tasks fully met the methodological characteristics of research-based training, which represents only $4 \%$ of the total.

A slightly different picture is observed at Master's degree level. According to the results of self-analysis teachers indicated $31 \%$ of disciplines (41 units) with tasks that correspond to the methodological characteristics of research-based training. According to the results of the critical analysis of the participants in the focus group, this percentage has decreased to $24 \%$ (31 disciplines). Such a percentage is quite permissible and is a normal indicator according to the requirements of a new law "On Higher Education" in Ukraine (2014).

Let us explain such a statement. According to the law "On Higher Education" in Ukraine (2014) Master's degree programs can be implemented on two levels: at educational-professional level or at educational-scientific level. The Institute of Human Sciences provides a Master's degree program on an educational-professional level. It means that the indicator of tasks that correspond to the methodological characteristics of research-based training is quite normal.

As for the professional training of specialists at Bachelor's degree level the percentage of disciplines that contain tasks corresponding to the methodological characteristics of research-based training is too low (only $4 \%$ ). Teachers were given a recommendation to review the structure of educational programs of disciplines with the aim of supplementing of tasks that correspond to the methodological characteristics of research-based training.

In addition to working with focus groups and self-examination of educational programs for the presence of tasks that meet the characteristics of research-based training, we have been investigating the personal motivation of the staff of the Institute of Human Sciences at Borys Grinchenko Kyiv University for the application of this kind of training. The survey involved 55 staff members of the Institute of Human Sciences. The characteristics of the respondents are given in the Table 3. 
Table 3. Respondents' characteristics.

\begin{tabular}{|c|c|}
\hline Age range & $24-64$ \\
\hline Gender (\%) & $\begin{array}{l}\text { Male-4 }(7.3 \%) \\
\text { Female-51 }(92.7 \%)\end{array}$ \\
\hline Position (\%) & $\begin{array}{l}\text { Assistant-2 }(3.6 \%) \\
\text { Lecturer-7 }(12.7 \%) \\
\text { Senior Lecturer-13 }(23.6 \%) \\
\text { Assistant Professor-27 }(49 \%) \\
\text { Professor-6 }(11.1 \%)\end{array}$ \\
\hline Education, scientific degree (\%) & $\begin{array}{l}\text { High education-55 }(100 \%) \\
\text { Without scientific degree-12 (22\%) } \\
\text { PhD-38 (69\%) } \\
\text { Doctor of sciences-5 }(9 \%)\end{array}$ \\
\hline
\end{tabular}

The survey was conducted after the respondents were acquainted with the methodological characteristics of research-based training. The questionnaire was conducted sending personal e-mail to the teachers and did not require the completion of the graph of personal information for complete anonymity. The questionnaire included a few questions:

1. Do you consider research-based training to be effective (yes, no)?

2. To what educational level should you apply research-based training elements (Bachelor's only, Master's only, both)?

3. What motivates you to apply research-based training elements? (estimate each of the proposed variants on the scale).

According to the results of the survey we received the following answers from respondents.

The answers to the first question (Do you consider research-based training to be effective (yes, no)?) were distributed in the following percentages (see Figure 1).

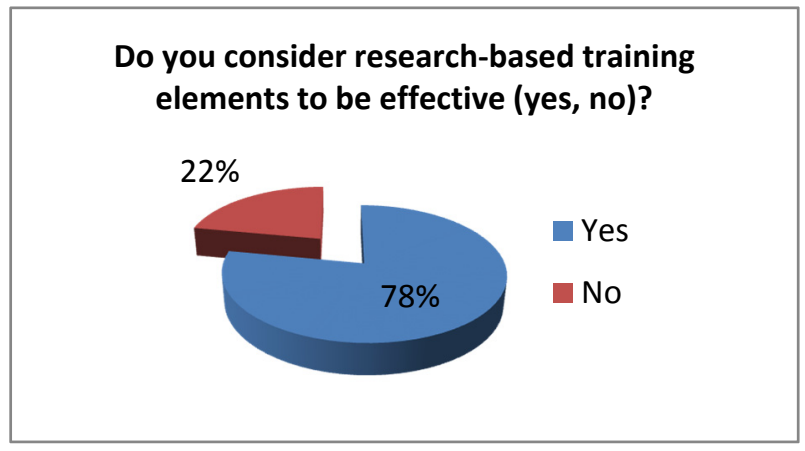

Figure 1. Do you consider research-based training to be effective (yes, no)?

Answers to the second survey question showed that the Institute of Human Sciences staff consider the application of research-based training elements to be effective on both levels (Bachelor's and Master's) (see Figure 2).

The third question of the survey (What motivates you to apply research-based training elements? (estimate each of the proposed variants on the scale)) was the most controversial and made it possible to understand the opinions of the staff of the Institute of Human Sciences regarding the effectiveness of the application of research-based training elements, their readiness for the implementation of this type of training and their motivation in the process of implementing changes in Ukraine's higher education system (see Table 4). 


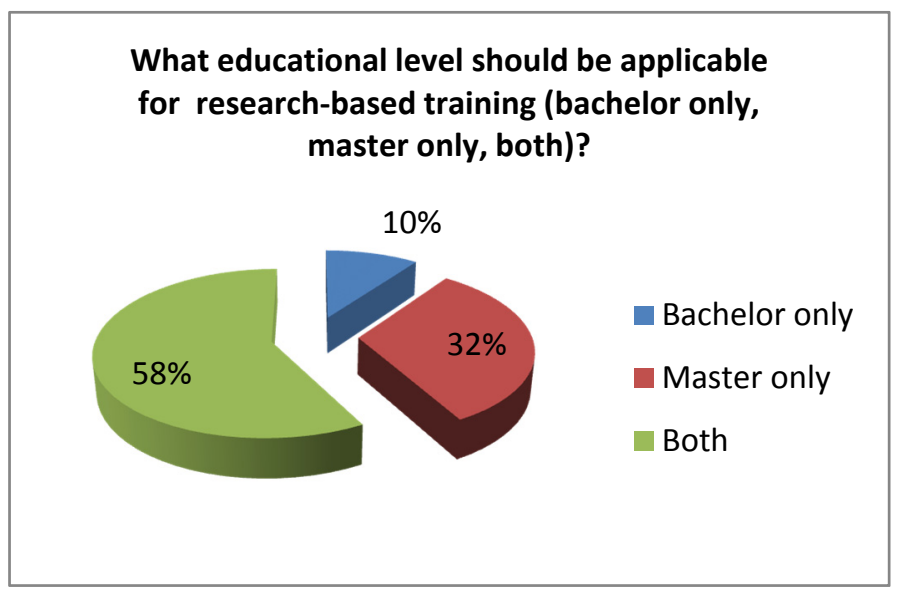

Figure 2. To what educational level should you apply research-based training elements (bachelor only, master only, both)?

Table 4. What motivates you to apply research-based training elements? (estimate each of the proposed variants on the scale).

\begin{tabular}{llcccc}
\hline$\#$ & \multicolumn{1}{c}{ Question } & Yes & More Yes Then No & More No Then Yes & No \\
\hline 1 & The interest in studying is increasing & $18(32 \%)$ & $23(41 \%)$ & $8(14 \%)$ & $6(10 \%)$ \\
\hline 2 & Develops creativity & $32(58 \%)$ & $14(25 \%)$ & $6(10 \%)$ & $3(5 \%)$ \\
\hline 3 & $\begin{array}{l}\text { Helps non-standard approach to } \\
\text { solving educational tasks }\end{array}$ & $17(30 \%)$ & $26(47 \%)$ & $9(16 \%)$ & $3(5 \%)$ \\
\hline 4 & $\begin{array}{l}\text { My personal rating among students } \\
\text { is increasing }\end{array}$ & $10(18 \%)$ & $11(20 \%)$ & $19(34 \%)$ & $15(27 \%)$ \\
\hline 5 & Forms research competence & $21(38 \%)$ & $28(50 \%)$ & $4(7 \%)$ & $2(3 \%)$ \\
\hline
\end{tabular}

\section{Discussion and Conclusions}

The results of the research (focus group work and self-analysis of training programs) make it possible to draw some conclusions. The participants of the focus group define research-based training as a set of pedagogical goals, which are united by the main tasks of developing research competence of students (development of skills for setting the research task and finding ways to solve it). This definition is mostly in line with the views of leading European and world scientists and practitioners in the research-based training system.

Based on the results of the work, the focus groups identified the main methodological characteristics of the research-based training system and they are also mostly coinciding with the views of foreign scientists. Important in this aspect is the understanding of Ukrainian teachers/researchers of the research-based training system's importance in the transition from a knowledge paradigm of training to a practice-oriented, competent, relevant contemporary European and world community's demands.

In general, our research is part of a comprehensive study of the Institute of Human Sciences-Vectors of the transition of the Institute of Human Sciences to a new quality of education. This study is devoted to the general new educational strategy aimed at the development of the teacher as a researcher and whole reorientation of the educational process to the practical level, the use of research-based training as a basis for linking connections between theory and practice, and the preparation of a new specialist for a new society of Ukraine (Bezpalko et al. 2016).

The work of focus groups and self-examination by teachers of their educational programs for the presence of tasks that correspond to the characteristics of the research-based training contributed to a rethinking by the teaching staff of general students' educational strategy. Thanks to this work, they made sure that this kind of training is much more effective and more interesting for both the 
student and the teacher. In addition, this type of training provides an effective learning system: theoretical training - practical training at the university_practical training on the basis of future employment-the definition of a research problem - the realization of a research problem. At each stage the roles of the teacher and the student change: the teacher and the student as subjects of learning in the sense of the development of intelligence and general outlook; a teacher as a tutor, a student as a future professional; teacher and student as colleagues-professionals; teacher and student as colleagues-researchers; teacher and student as full and equal performers of research. Such a system still needs to test its effectiveness in the sense of activities of the teacher and student.

At the same time, applying the research-based training system it is important to understand the motivation of university teachers to apply this type of training, and their understanding of its effectiveness. In our study, there was a positive motivation of the teachers of the Institute of Human Sciences prior to the transition to a research-based training system and a high level of understanding of the effectiveness of such a system for the training of a highly skilled specialist.

From the motivation survey's results we see that most of the staff of the Institute of Human Sciences: (i) are interested in applying of new types and methods of training to increase the interest of students in the learning process ( 42 people, $76 \%$ ); (ii) are motivated to develop the creativity as a necessary skill of a modern specialist (46 people, 83\%); (iii) are ready to use non-standard decisions in achieving of educational goals (43 people, 78\%); (iv) understand the need to develop the research competence of a modern specialist (49 people, $89 \%$ ); and (v) do not put their personal interests first, but direct their activities to the formation of a future professional skills (34 people, $61 \%$ ).

After the teachers' self-examination and the focus group activities, the Institutional Forum "Research-based training in education quality assurance" for the scientific and pedagogical staff of the Institute of Human Sciences at Borys Grinchenko Kyiv University was held. This topic is chosen through a number of issues on which the teaching staff of the Institute of Human Sciences is working. One of them is the provision of quality of education and its ongoing monitoring (Bezpalko et al. 2016).

The results of teachers' self-examination of their own educational programs of disciplines for the presence of tasks that correspond to the methodological characteristics of research-based training, and the results of expert evaluation of the participants of the focus groups were presented at the Institutional Forum. Also presented was the foreign experience and concrete examples of implementation of research-based training.

In addition, staff members were invited to jointly analyze all their assigned tasks that correspond to the methodological characteristics of research-based training, and identify from 1 to 5 best practices and present them at the Institutional Forum in order to present best practices for the application of the elements of research-based training.

Thus, the practice of applying the case-study method in the training of future speech therapists was presented by the Department of Special Psychology, Correctional and Inclusive Education staff. Their practice is that during the practical training of students a fairly large range of cases is being used. The cases are prepared by the students themselves, in co-operation with the teachers, and by the teachers. During the course students can not only get practical experience in speech therapy with children who have different speech and developmental disorders, but also conduct a mini-study on a particular issue of speech development and general psychological development.

The staff members of the Department of Practical Psychology presented the system of phased involvement of students into scientific work through various types of research tasks that are used in the teaching of different disciplines and in various courses (at the undergraduate level, at the master's degree, and at the level of postgraduate study).

A similar system was presented by the staff members of the Department of Social Pedagogy and Social Work. The difference was that teachers identified the specific disciplines of the professional training unit and professional practices that with the transition from the course to course involve students using previously acquired skills for conducting certain mini-studies and performing research tasks. 
The teaching staff of the department of General, Age and Pedagogical Psychology presented the experience of the research partnership in ensuring the quality of higher education. The main issue was presented in the form of involving students of joint research with teachers during the study of various disciplines, making course and master's projects and participation in scientific projects of the department as researcher on equal rights with the teachers.

Conclusions and results of this study should be taken into account in light of certain limitations. First, qualitative research cannot be generalized by its nature. This means that the results of this study cannot be presentable for other institutes at Borys Grinchenko Kyiv University or universities of Ukraine. Secondly, the study was limited to the participation in focus groups of only teachers of the Institute of Human Sciences. Thus, the experience of teachers from other universities is not presented in this study.

In conclusion, this study makes it clear that planning approaches that meet the characteristics of research-based training should be based on how teachers should understand the methodological characteristics of this type of learning and approach to the use of such tasks carefully without overloading students with research tasks, neglecting the formation of professionally meaningful competencies.

\section{Materials and Methods}

At the first stage of our study, the focus group method was applied. Its goal was to obtain the necessary information from the participants to describe the methodological basis and justify the methods, forms, indicators, etc. of research-based training among competent persons and among people who have practical experience in this field.

The focus group method is a group interview conducted by a moderator in a pre-designed scenario with a small group of representatives of the researched contingent of respondents, similar in basic social characteristics. Our focus group was conducted according to the methodology developed by American sociologists Robert K. Merton, Patricia L. Kendall, which is now the most relevant one (Merton and Kendall 1946).

Respondents were attracted to the focus group through announcements posted on the website of the Institute Human of Sciences at Borys Grinchenko Kyiv University and suggestions in a personal letter to the staff members and heads of the departments.

For the focus groups there were selected two equal-number (8 people) groups among the Institute of Human Sciences at Borys Grinchenko Kyiv University staff. Such a choice is due to the fact that the representatives of this institute expressed the desire to participate in the study and try to analyze existing educational programs to determine the presence of research-based training tasks. In general, the Institute of Human Sciences at Borys Grinchenko Kyiv University consists of 4 departments: (i) general, age and pedagogical psychology; (ii) practical psychology; (iii) special psychology, correctional and inclusive education; (iv) social pedagogy and social work. Accordingly, from each structural unit 4 persons were selected, which differ in scientific degrees, work experience, and have a common field of activity-the humanities.

The first focus group included experienced scientists and lecturers who have more than 10 years of teaching experience (teaching at a high school), are doctors of sciences and PhDs, associate professors and professors. The second focus group was composed of teachers who had a pedagogical experience of less than 10 years, are not PhDs (except 1 ) and doctors of sciences, associate professors and professors. This division made it impossible for the more-experienced colleagues to pressure the less-experienced, which allowed the authors to compare the insights of the participants of the focus groups (see Table 5).

As a result of the work of the focus groups' methodological characteristics, features, forms and methods of research-based training were determined, after which the method of "theoretical sampling" was used (Glaser and Strauss 2012). This method makes it possible to formulate more specific questions for self-examination by lecturers of higher educational institutions of their own educational programs of disciplines. In addition, such a method enabled the formulation of generalized characteristics by the results of focus groups. 
Table 5. Focus groups participants.

\begin{tabular}{|c|c|c|}
\hline & Focus Group 1 & Focus Group 2 \\
\hline Total & 8 & 8 \\
\hline Age range & $32-55$ years & $32-55$ years \\
\hline Experience (\%) & $\begin{array}{c}1-5 \text { years }-0 \\
5-10 \text { years }-3(37.5 \%) \\
\text { More than } 10 \text { years- } 5(62.5 \%)\end{array}$ & $\begin{array}{l}1-5 \text { years }-3(37.5 \%) \\
5-10 \text { years- } 5(62.5 \%) \\
\text { More than } 10 \text { years- } 0\end{array}$ \\
\hline Position (\%) & $\begin{array}{c}\text { Lecturer-0 } \\
\text { Senior Lecturer-0 } \\
\text { Assistant Professor-4 }(50 \%) \\
\text { Professor-4 }(50 \%)\end{array}$ & $\begin{array}{c}\text { Lecturer-4 (50\%) } \\
\text { Senior Lecturer-4 (50\%) } \\
\text { Assistant Professor-0 } \\
\text { Professor-0 }\end{array}$ \\
\hline Education, scientific degree (\%) & $\begin{array}{l}\text { High education-8 (100\%) } \\
\quad \text { PhD—4 (50\%) } \\
\text { Doctor of sciences-4 (50\%) } \\
\text { Without scientific degree-0 }\end{array}$ & $\begin{array}{c}\text { High education-8 }(100 \%) \\
\text { PhD-1 }(12.5 \%) \\
\text { Doctor of sciences-0 } \\
\text { Without scientific degree-7 (87.5\%) }\end{array}$ \\
\hline
\end{tabular}

For the next stage of the study-self-examination of educational programs by the staff of the Institute of Human Sciences at Borys Grinchenko Kyiv University-a methodological description of the main characteristics of research-based training were proposed, which were developed as a result of the activity of two focus groups. Accordingly, they had to determine the presence of research-based training elements in the educational curricula of the disciplines they taught at the bachelor's and master's levels.

After working out the methodological basis, lecturers were asked to analyze their own programs for the presence of signs, goals, forms, elements, subspecies, and tasks of research-based training. The results had to be drawn in the form of a table.

Acknowledgments: The research is done within the evaluation of scientific theme of the Institute of Human Sciences "Personality in terms of social transformations of modern Ukraine", Registration Number 0116U002960, term of implementation-May 2016-May 2021.

Author Contributions: Roman O. Pavliuk and Tetiana L. Liakh conceived and designed the experiments; Nataliia A. Klishevych performed the experiments; Olga V. Bezpalko and Tetiana L. Liakh analyzed the data; Roman O. Pavliuk wrote the paper.

Conflicts of Interest: The authors declare no conflict of interest.

\section{References}

Abbott, Martin Lee, and Jennifer McKinney. 2013. Understanding and Applying Research Design. Hoboken: John Willey \& Sons, Inc.

Aditomo, Anindito, Peter Goodyear, Ana-Maria Bliuc, and Robert A. Ellis. 2013. Inquiry-based learning in higher education: Principal forms, educational objectives, and disciplinary variations. Studies in Higher Education 38 : 1239-58. [CrossRef]

Baldwing, Gabrielle. 2005. The Teaching Research Nexus: How Research Informs and Enhances Learning and Teaching in the University of Melbourne. Melbourne: The University of Melbourne. Available online: http:/ /www.cshe. unimelb.edu.ua (accessed on 17 December 2017).

Batechko, Nina Gryhorivna. 2016. Theoretical and Methodical Basis of Future Higher School Teachers' Preparation in Conditions of Master's Program. Abstract of Doctor of Sciences thesis, National University of Bioresources and Natural Resources of Ukraine, Kyiv, Ukraine.

Bezpalko, Olga, Tetiana Liakh, Nataliia Klishevych, and Roman Pavliuk. 2016. Criteria and indicators of university education quality: The results of expert interview. The New Education Review 46: 61-71. [CrossRef]

Blackmore, Paul, and Moira Fraser. 2007. Researching and teaching: Making the link. In Towards Strategic Staff Development in Higher Education. Edited by Paul Blackmore and Richard Blackwell. Maidenhead: McGraw-Hill International, pp. 131-41.

Bondarenko, Natalia Oleksandrivna. 2014. Pedagogical Conditions of Scientific and Research Training of Masters of Social Pedagogy. Abstract of Ph.D. thesis, Hryhorii Skovoroda Pereiaslav-Khmelnytskii State Pedagogical University, Pereiaslav-Khmelnytsrii, Ukraine. 
Dewey, John. 1933. How We Think: A Restatement of the Relation of Reflective Thinking to the Educative Process. Boston: D.C. Heath.

Fedirchyk, Tetiana Dmytrivna. 2016. Theoretical and Methodical Basis of Development of Pedagogical Professionalism of Young Lecturer during Scientific-Pedagogical Activities. Doctor of Sciences thesis, Yurii Fedkovych Chernivtsi National University, Chernivtsi, Ukraine.

Glaser, Barney G., and Anselm L. Strauss. 2012. The Discovery of Grounded Theory: Strategies for Qualitative Research. New Brunswick and London: Aldine Transaction.

Healy, Mick. 2005. Linking research and learning to benefit student learning. Journal of Geography in Higher Education 29: 183-201. [CrossRef]

Humbold, Von Wilhelm. 1984. Der Köningsbrger Schulplan, 1809. In Schriften zur Anthropologie und Bildunslehre. Edited by Andreas Flitner. Frankfurt Am Main: Ullstein, pp. 69-76.

Ifenthaler, Dirk, and Maree Gosper. 2014. Research-based learning: Connecting research and instructions. In Curriculum Models for the 21st Century: Using Learning Technologies in Higher Education. New York: Springer, pp. 73-89.

Justice, Christopher, James Rice, and Wayne Warry. 2009. Academic skill development-Inquiry seminars can make a difference: Reflections and directions on course design and teaching methods. Innovative Higher Education 3.

Lageman, Ellen Condliffe. 2002. Experimenting with education: John Dewey and Ella Flagg Young at the University of Chicago. In Feminist Interpretations of John Dewey. Edited by Charlene Haddock Seigfried. University Park: Penn State University Press, pp. 31-46.

Levy, Philippa, and Robert Petrulis. 2012. How do first year university students experience inquiry and research, and what are the implications for the practice of inquiry-based learning? Studies in Higher Education 37: 85-101. [CrossRef]

Ludwig, Joachim. 2011. Forschungsbasierte Lehre als Lehre im Format der Forschung. Available online: http:/ / www.sq-brandenburg.de/files/bbhd03.pdf (accessed on 17 December 2017).

Lutsenko, Iryna Volodymyrivna. 2011. The Formation of Research Culture of Future Teachers in the Activities of Students Scientific Society. Abstract of Ph.D. thesis, Taras Shevchenko Luhansk National University, Luhansk, Ukraine.

Merton, Robert K., and Patricia L. Kendall. 1946. The Focused Interview. The American Journal of Sociology 51: 541-57. [CrossRef]

Mills, Julie E., and David F. Treagust. 2003. Engineering education-Is problem-based or project-based learning the answer? Australasian Journal of Engineering Education. Available online: http:/ / citeseerx.ist.psu.edu/ viewdoc/download?doi=10.1.1.620.5767\&rep=rep1\&type=pdf (accessed on 17 December 2017).

Prince, Michael J., and Richard M. Felder. 2006. Inductive teaching and learning methods: Definitions, comparisons, and research bases. Journal of Engineering Education 95: 123-38. [CrossRef]

Prince, Michael J., and Richard M. Felder. 2007. The many faces of inductive teaching and training. Journal of College Science Teaching 36: 14-20.

Proshkin, Volodymyr Vadymovych. 2012. The Essential Characteristics of the Integration of Research and Training Work in the University Training of Future Teachers. Bulletin of Taras Shevchenko LNU 22: 77-83.

Pryima, Serhii Mykolaiovych. 2016. Theoretical and Methodical Basis of Projecting and Functioning of the System of Open Adult Education in Ukraine. Doctor of Sciences thesis, Hryhorii Skovoroda Kharkiv National Pedagogical University, Kharkiv, Ukraine.

Spoken-Smith, Rachel, and Rebecca Walker. 2010. Can Inquiry-based Learning Strengthen the Links Teaching and Disciplinary Research? Studies in Higher Education 35: 723-40. [CrossRef]

Thomas, John W. 2000. A Review of Research on Project-Based Learning. Research Review; California: The Autodesk Foundation.

Wildt, Johannes. 2010. Forschendes Lernen: Wie und Warum? Presentation at Leibniz University Hannover, October 13. Available online: https://www.zqs.uni-hannover.de/fileadmin/institut/pdf/Forschendes_ Lernen_Leibniz_Universitaet_Hannover_Prof._Dr._Dr._Wildt_13.10.2011.pdf (accessed on 17 December 2017).

(C) 2017 by the authors. Licensee MDPI, Basel, Switzerland. This article is an open access article distributed under the terms and conditions of the Creative Commons Attribution (CC BY) license (http:/ / creativecommons.org/licenses/by/4.0/). 